\title{
Cervical cancer screening in pregnancy at the maternity clinics of Nabil Choucair health center and the Institute of Social Hygiene of Dakar, Senegal: a study on 67 cases
}

\author{
Omar Gassama*, Mouhamadou Mansour Niang, Marie Edouard Faye Dieme, \\ Ousmane Thiam, Mamour Gueye, Mame Diarra, Ndiaye Gueye, Philippe Marc Moreira, \\ Djibril Diallo, Mamadou Lamine Cisse, Cheickh Tidiane Cisse, Jean Charles Moreau
}

\begin{abstract}
Department of Obstetrics and Gynecology, Obstetrics and Gynecology Clinic, Teaching Hospital Aristide Le Dantec,
\end{abstract} Cheikh Anta Diop University, Dakar, Senegal

Received: 11 March 2017

Accepted: 07 April 2017

*Correspondence:

Dr. Omar Gassama,

E-mail: ogasse79@yahoo.fr

Copyright: $(\odot$ the author(s), publisher and licensee Medip Academy. This is an open-access article distributed under the terms of the Creative Commons Attribution Non-Commercial License, which permits unrestricted non-commercial use, distribution, and reproduction in any medium, provided the original work is properly cited.

\section{ABSTRACT}

Background: This study aims were to develop the epidemiological profile of patients who received Pap smears during pregnancy, to describe aspects of cytological smears performed in pregnant women and to describe the therapeutic management in case of anomalies in the cervical smear during pregnancy.

Methods: This was a prospective, descriptive and analytical study conducted from January 15, 2015 to June 31, 2015 at maternity of Nabil Choucair Health Centre and the Institute of Social Hygiene in Dakar. The Pap smear was performed in all patients who had given their consent to the experience. The parameters studied concerned sociodemographic aspects, gynecological and obstetric background, gestational age at the time of collection, cervicovaginal smear results, diagnostic and therapeutic management of cytological and histological abnormalities. The data collected on a survey sheet prepared for this purpose were entered and analyzed through the version 3.5.3 of Epi info software.

Results: During the study period, 67 pregnant women had received a Pap smear. The epidemiological profile of our patient was a paucipare gestity with an average of 3 with extremes ranging from 1 to 7 , an average parity of 2.4 with extremes ranging from 1 to 7. The mean age of pregnancy was 15.4 weeks of amenorrhea (range of 6 and 32 weeks). Only 5 patients $(7.4 \%)$ had already received a cervical-vaginal swab before the study. The smear was normal in $88.7 \%$ of the cases but got abnormalities in $11.3 \%$ of the cases. The abnormalities were mainly found in squamous cells and were divided into low-grade lesions $(57.1 \%)$ and skew-cell abnormalities whose meaning was undetermined $(42.1 \%)$. Colposcopy was performed in 8 patients. Colposcopy was normal and satisfactory in 4 patients $(50 \%)$ and identified as atypical grade 1 transformation in 2 patients (25\%) and an atypical grade 2 transformation in 2 patients $(25 \%)$. From a therapeutic point of view, diathermic loop conduction associated with strapping was performed in one patient $(12.5 \%)$ for severe dysplasia. In postpartum, all dysplastic cervical lesions diagnosed during pregnancy had declined.

Conclusions: In the context of our study, where there is no organized screening policy for cervical cancer, antenatal clinics are an excellent screening opportunity to seize.

Keywords: Cervical cancer, Colposcopy, Conization, Pap smear, Pregnancy 


\section{INTRODUCTION}

Cervical cancer is a public health issue. Each year, 585,000 new cases are detected worldwide and this disease causes 265,000 deaths. ${ }^{1,2}$ More than $85 \%$ of women affected by cervical cancer live in developping countries. ${ }^{1,2}$ In Senegal, there are approximately 1,482 new cases and 858 deaths each year. These figures are attributable to delayed diagnosis due to the lack of organized programmes and strategies of cervical cancer screening. ${ }^{3}$ Pregancy is therefore a prime opportunity to detect cervical displasias. ${ }^{2,4-6}$

The objectives of this study were to determine the epidemiological profile of the pregnant women who got pap smears, to describe the cytological aspects as well as the diagnostic and treatment of cervical abnormalities during pregnancy.

\section{METHODS}

\section{Type of study and reporting period}

This is a prospective and descriptive study conducted in two areas. One is the maternities of Nabil Choucair Health Center and another that of the Institute of Social Hygiene, both located in the semi-urban area of Dakar. It was conducted over the period stretching from January 15 , to June 31,2015 (six months).

\section{Inclusion criteria}

In our study, we included any parturient woman with a normal intrauterine pregnancy confirmed by an obstetrical ultrasound.

\section{Non-inclusion criteria}

In this study, we excluded in utero foetal deaths, any nonpregnant patient or those whose pregnancy test was not confirmed by ultrasound or patients whose pap smear was perfomed less than a year ago.

\section{Data collection}

This study focused on parameters such as sociodemographic aspects, obstetric and gynecological history, the gestational age at the time of examination, the results of pap smear, diagnosis and therapeutic treatment of cytological and histological abnormalities. For conventional pap smear, the specimens were collected in various cytology laboratories located in Dakar. As for liquid pap smears, specimens were collected at Institute Pasteur de Dakar or at the BIO 24 laboratory. All patients with cytologic abnormalities, according to the Bethesda classification, had undergone colposcopy.

When confronted with abnormalities detected through colposcopy, we carried out a biopsy which was taken to anatomical pathology laboratories located in the Dakar area.

Only patients with micro-invasive carcinoma revealed by colposcopy biopsy had undergone cone biopsy through diathermy loop. This cone biopsy was performed after a cerclage.

\section{Data entry and analysis}

The data gathered on a tailored survey form were entered and analysed using Epi info software, version 3.5.3.

\section{RESULTS}

\section{Socio-demographic characteristics}

Age

The average age of pregnant women included in this study was 31.8 with extremes ranging from 18 to 45 years old.

In half of the cases (50\%), pregnants were aged between 30 and 39.

\section{Marital status}

All pregnant were married.

Gestity

The average number of pregnancies was 3 with extremes going from 1 to 7 .

In our study, 37 patients $(55,9 \%)$ had been pregnant at least 3 times.

\section{Parity}

Mean parity was 2.4 with extremes going from 0 to 8 . The number of paucipares, multiparous and nulliparous were $36(54,2 \%), 20(30,5 \%)$ and $10(15,3 \%)$ respectively.

\section{Marriage age}

The average age of marriage was 22.2 years with extremes going from 12 to 35 years.

\section{Age at first sexual intercourse}

The average age at first intercourse is 21.7 years with extremes going from 12 to 35 years.

\section{Age of the first pregnancy}

The average age at the first pregnancy was 24.4 years with extremes going from 17 to 37 years. 


\section{Clinical and cytological data}

\section{Gestational age}

The average gestational age was 15.4 weeks of amenorrhea with extremes going from 6 to 32 weeks. In almost half of the cases (40.3\%), the gestational age was between 6 and 11 weeks of amenorrhea, as showed in Table 1.

Table 1: Distribution of patients according to the gestational age.

\begin{tabular}{|lll|}
\hline Gestational age & Number (n) & Percentage (\%) \\
\hline 6-11 WA & 27 & $40.3 \%$ \\
\hline 12-17WA & 23 & $34.4 \%$ \\
\hline $18-23$ WA & 7 & $10.3 \%$ \\
\hline $24-29$ WA & 7 & $10.3 \%$ \\
\hline$\geq 30$ WA & 3 & $4.5 \%$ \\
\hline Total & 67 & $100 \%$ \\
\hline
\end{tabular}

\section{Results of pap smear}

\section{Type of environment}

In more than half of the cases $(51.6 \%)$, the pap smear was performed in a liquid environment.

\section{Cytological aspects}

In most cases $(88.7 \%)$, the pap smear did not show any cervical dysplasia as indicated in Table 2. Among patients with abnormal pap smear, 5 had low-grade lesions $(57.1 \%)$ and 3 had squamous cells lesions of undetermined significance (42.9\%) (Table 2).

Table 2: Distribution of patients according to the results of pap smear.

\begin{tabular}{|lll|}
\hline Results of pap smear & N & $\%$ \\
\hline Normal & 59 & $88.7 \%$ \\
\hline Abnormal & 8 & $11.3 \%$ \\
- LSIL & 5 & $57 \%$ \\
- ASC-US & 3 & $47 \%$ \\
\hline
\end{tabular}

\section{Bacteriological aspects}

In our study, $21 \%$ of pregnant patients developed inflammation and $25 \%$ had a Gardnerella Vaginalis, Candida Albicans, Trichomonas Vaginalis and Chlamydiae Trachomatis infection in respectively $60 \%$, $20 \%, 13.3 \%$ and $6.7 \%$ of cases.

\section{Colposcopic aspects}

In our study, 8 patients $(11.3 \%)$ had undergone a colposcopy. At the end of the coloposcopy, 4 patients $(50 \%)$ had normal and satisfactory results for 1 ASC-US smear and for 3 LSIL smear, 2 patients (25\%) had a grade-1 atypical transformation with a satisfactor colposcopy for one LSIL smear and 2 patients $(25 \%)$ had a grade-1 atypical transformation with one nonsatisfactory colposcopy which prompted us to perform 2 biopsies after 1 ASC-US smear and 1 LSIL smear. Biopsies revealed one CIN1 and one CIN3 in which we could not rule out a micro-invasion (Table 3 ).

Table 3: Results of pap smears, colposcopies and histologies.

\begin{tabular}{|c|c|c|c|}
\hline & $\begin{array}{l}\text { Pap } \\
\text { smears }\end{array}$ & Colposcopies & Histologies \\
\hline Patient 1 & $\begin{array}{l}\text { ASC- } \\
\text { US }\end{array}$ & $\begin{array}{l}\text { Normal and } \\
\text { satisfactory }\end{array}$ & \\
\hline Patient 2 & LSIL & $\begin{array}{l}\text { Normal and } \\
\text { satisfactory }\end{array}$ & \\
\hline Patient 3 & LSIL & $\begin{array}{l}\text { Normal and } \\
\text { satisfactory }\end{array}$ & \\
\hline Patient 4 & LSIL & $\begin{array}{l}\text { Normal and } \\
\text { satisfactory }\end{array}$ & \\
\hline Patient 5 & LSIL & $\begin{array}{l}\text { Grade-1 atypical } \\
\text { transformation } \\
\text { Satisfactory } \\
\text { colposcopy }\end{array}$ & \\
\hline Patient 6 & LSIL & $\begin{array}{l}\text { Grade-1 atypical } \\
\text { transformation } \\
\text { Satisfactory } \\
\text { colposcopy }\end{array}$ & \\
\hline Patient 7 & LSIL & $\begin{array}{l}\text { Grade- } 2 \text { atypical } \\
\text { transformation } \\
\text { Non-satisfactory } \\
\text { colposcopy }\end{array}$ & $\begin{array}{l}\text { Cervical intra } \\
\text { epithelial } \\
\text { Neoplasia } \\
\text { (CIN) } 1\end{array}$ \\
\hline Patient 8 & $\begin{array}{l}\text { ASC- } \\
\text { US }\end{array}$ & $\begin{array}{l}\text { Grade- } 2 \text { atypical } \\
\text { transformation } \\
\text { Non-satisfactory } \\
\text { colposcopy }\end{array}$ & $\begin{array}{l}\text { Cervical intra } \\
\text { epithelial } \\
\text { Neoplasia } \\
\text { (CIN) } 3\end{array}$ \\
\hline
\end{tabular}

\section{Therapeutic aspects}

We performed a cone biopsy for one CIN3 in which the pathologist could not rule out a micro-invasion. This cone biopsy was done using a diathermy loop under spinal anaesthesia, and it was associated with a stitching.

\section{DISCUSSION}

\section{Socio-demographic characteristics}

For 20 years, the number of precancerous lesions has been on the rise among young women, increasing thereby the likelihood of the presence of these lesions in pregnant women. ${ }^{5,7}$ The epidemiological profile used in this study was a paucipare ( 3 deliveries on average) aged 31.8 on average, with a mean parity of 2 , who had her first sexual intercourse at 21 and who got married at the age of 22 . Our findings are not very different from those prsented in the literature. ${ }^{5,7}$ In Senegal, the 2010 Demographic and Health Survey had revealed a maximun fertility level 
between 20 and 29 years with an average age of 22 at the first sexual intercourse. In France, the age of the first pregnancy is around 30 .

The diagnosis of precancerous lesions of the cervix in this country is around $30-35$ years, which is the highest age range for dysplasias but also the age range of occurrence of pregnancies. ${ }^{3,8-10}$

\section{Clinical aspects}

There is no consensus on the ideal phase of pregnancy at which pap smear should be perfomed. ${ }^{2}$

In our study, the average gestational age was 15.4 weeks.

In France, according to the recommendations by the Haute Autorité de la Santé, pap smear should be performed before the $14^{\text {th }}$ week of Amenorrhea. ${ }^{6}$

The late gestational age among our patients is probably due to the age of the first prenatal visit which is often delayed in the Senegalese context.

In its anti-cervical cancer guide, the WHO declares that not suggesting the detection of cervical cancer during pregnancy should be considered as a lost opportunity. We systematically offered screening to all pregnant women who signed the consent form because our patients had never undergone a cervical cancer screening before pregnancy. $^{2}$

\section{Cytological aspects}

More than half of the patients $(51 \%)$ did the smear on a liquid environment.

The detection of cervical cancer through cervical cytology is supposed to result in $5 \%$ of conclusive tests in gynecological period. These figures are the same in obstetrical period. The reliability of pap smear during pregnancy is the same for the gynecological period. An over-estimation of $20.5 \%$ and an underestimation of $24 \%$ according to Baldauf. ${ }^{11}$

We registered more than three-quarters (59 patients) (i.e. $88.7 \%$ ) of pregnant women with a normal pap smear.

In our study, 8 patients $(11.3 \%)$ showed cervical dysplasias when subjected to pap smear.

Our findings are different from those in the existing litterature which shows a $5 \%$ rate.

The difficulties in making cytological interpretations are due to the fact that there is an important level of hormons during pregnancy, which results in sizeable cytological modifications. One of the most common cytological elements is the presence of cervical cells called navicular cells. Moreover, pregancy is responsible for stromal gland hyperplasia, decidualization with the presence of Aria stella cells which could be confused with cellular atypias and of metaplasia of pregnancy ectropion. ${ }^{10,13-17}$

The distribution of lesions revealed by pap smear during pregnancy varies according to the centers and to the recruitment mode, but remains similar with those found in gynecological period with a predomiance of low-grade lesions. ${ }^{4,15,16}$

In our study, 5 patients $(57.1 \%)$ had smear showing lowgrade lesions and 3 patients $(42.9 \%)$ had a pap smear with atypical squamous cells of undetermined significance.

Inflammation is common during pregnancy. In our study, $21 \%$ of parturients had an inflammation of the uterine cervix.

$25 \%$ of patients had an infection. The germs responsible for those infections were Gardnerella Vaginalis in $60 \%$ of cases, Candida Albicans in $20 \%$ of cases and Trichomonas Vaginalis in $13.3 \%$ of cases.

\section{Colposcopic aspects}

The systematic performance of colposcopy during pregnancy in order to detect dysplasias is a matter of controversy.

The HAS (Haute Autorité de la Santé) in France recommends the systematic performance of colposcopy in case of dysplasia. ${ }^{6}$

The joint clinical guideline of the Societies of obstetrics, gynecology and cancerology of Canada recommends that a new detection pap smear be performed three months after the delivery in case of low grade squamous lesions and squamous cells of undertermined significance. ${ }^{17}$

All our patients with cervical abnormalities revealed through pap smear had undergone a colposcopy. Indications were respectively low grade lesions in $57.1 \%$ of cases and abnormal squamous cells of undertermined significance in $42.9 \%$ of cases.

During pregnancy, colposcopy shows some characteristic with a posterior cervix and bloated cervix linings, which decrease cervical exposure, hence the need to use a Collin speculum or lateral valves.

In our study, 5 patients $(62.5 \%)$ had a normal and satisfactory colposcopy.

This figure is similar with those found in the literature.

In our study, the average gestational age was 15.4 weeks.

After the first quarter, cytology shows false positives due to pregnancy-related changes in the cervix such as 
deciduosis with the presence of Aria Stella cell which can be confused with atypias as well as the presence of trophoblastic degenrated cells.

Biopsies showed one CIN1 and one CIN3 for low grade cervical abnormallities and for abnormal squamous cells of undertermined significance respectively.

The cytology-histology agreement for the diagnosis of low grade lesions was $20 \%$.

In the literature, the agreement rate varies between 58 and $86 \%$.

The Colposcopy-biopsy correlation during pregnancy is excellent and varies between $73 \%$ and $95 \% .^{10,11,14,15}$ In our study, this rate was $100 \%$.

\section{Therapeutic aspects}

The management of patients depends on 3 aspects: cytology, colposcopy and histology.

Intraepithelial neoplasias in pregnant women must be treated depending on specificities of the pregnancy. we should neither give unsufficient treatment to mothers nor impose a risky therapy on them during pregnancy.

Abstention is highly recommended in cases of dysplastic lesions revealed by histology during pregnancy. The treatment is authorised only in case of micro-invasive carcinoma discovered during pregnancy. ${ }^{10,17,18}$

If cytology, colposcopy and biopsy can't eliminate an invasion, a loop electrosurgical excision procedure should be proposed. ${ }^{5,12}$

The histological study of the conisation resected specimen a CIN2 intermediary cervical dysplasia.

\section{Post-partum monitoring}

The evolution of dysplasias during pregnancy is either stable or regressing. Progressions are rare $(\leq 5 \%)$. The few cases of invasive cancers diagnosed in the postpartum phase after a surveillance during pregancy seem to correspond to lesions more serious than expected and which were « missed » by colposcopy or biopsy. ${ }^{4,7,8,18}$

In our study, all the patients with cervical dysplasias revealed by cervical cytology had a pap smear two months after giving birth. Pap smear did not show any cervical abnormalities.

\section{CONCLUSION}

Cervical cancer remains a real public health issue. Developing countries like Senegal are characterized by the absence of organized programmes of cervical cancer screening. For us, detecting cervical cancer during prenatal visits is an excellent opportunity that should be siezed. We should therefore sensitize and train all health care providers who monitor and manage pregnancy on the detection of cervical precancerous lesions.

Funding: No funding sources

Conflict of interest: None declared

Ethical approval: Not required

\section{REFERENCES}

1. International Agency for Research on Cancer, World Health Organization. Latest world statistics, global cancer burden rises to 14.1 million new cases in 2012. Marked increase in breast cancer must be addressed Press Release N 223 December 2013.

2. World Health Organization. Essencial practices Guide. Fighting cervical cancer World Health Organization; 2007:300.

3. ICO (Institut Català Oncologia) Information center on HPV and cancer. Senegal: Human Papillomavirus and related cancers fact sheet, Dec 15, 2014.

4. Zoundi-Ouango O, Morcel K, Classe JM, Burtin F, Audrain O, Levêque J. Lésions cervicales utérines pendant la grossesse: diagnostic et prise en charge. Journal de gynécologie obstétrique et biologie de la reproduction. 2006 May 1;35(3):227-36.

5. Selleret L, Mathevet P. Diagnostic Et Prise En Charge Des Lésions Précancéreuses Du Col Utérin Pendant La Grossesse. Gynécol Obstet Biol Repro. 2008;37SL:S131-8.

6. Haute Autorité de Santé de la France Dépistage Et Prévention Du Cancer Du Col De L'utérus: Actualisation Du Référentiel De Pratiques De L'examen Périodique De Santé (EPS); 2013.

7. Monsonego J. Infections à human papillomavirus: Etats des connaissances, pratiques et prévention vaccinale. Springer, Paris; 2006:264.

8. Agence Nationale De La Statistique Et De La Démographie (Sénégal). Enquête Démographique et de Santé à Indicateurs multiples au Sénégal (EDSMICS), 2010-2011. Calverton, Maryland, USA: ANDS et ICF International.

9. Mc Donnell JM, Mylotte MJ. Colposcopy in pregnancy: a 12-year review. Br J Obstet Gynecol. 1981;88:914-20.

10. Kaplan. Prognosis and recurrence risk for patients with cervical squamous intraepithelial lesions diagnosed during pregnancy. Cancer. 2004;102:2228-32.

11. Baldauff JJ. Colposcopy and directed biopsy during pregnancy: a cohort study. Eur J Obstet Gynecol Reprod Biol. 1995;62:31-6.

12. Marchetta J, Deschamps P. La colposcopy: techniques et diagnostics. Ed. Elsevier Masson Belgique; 2008:196.

13. Muszinsky C, Gondry J. Cervical intraepithelial neoplasia and invasive cervical cancer: some specificities to be known. General Cancer Journals, Gynecology and Obstetrics Realities. 2013;127. 
14. Morimura Y. Cervical cytology during pregnancy: comparison with no-pregnant woman and management of pregnant woman with abnormal cytology Fukishima J Med Sci. 2002;48:27-37.

15. Benedet JL. Colposcopic evaluation of abnormal papanicolaov smears in pregnancy. Am J Obstet Gynecol. 1987;157:932-7.

16. Michael CW. Pregnancy-related changes: a retrospective review of 278 cervical smears. Diagn cytopathol. 1997;17:99-107.

17. National Institute of Public Health, Quebec. Guidelines for Cervical Cancer Screening in Quebec;
2016. available at https // www.inspq.qc.ca / pdf ... / 1279_LignesDirectDepistCancerCo.

18. Calsteren V. Cervical néoplasia during pregnancy: diagnosis, management and prognosis. Best Pract Research Obstet Gynaecol. 2005;19:611-30.

Cite this article as: Gassama O, Niang MM, Dieme MEF, Thiam O, Gueye M, Diarra M, et al. Maternity clinics of Nabil Choucair health center and the Institute of Social Hygiene of Dakar, Senegal: a study on 67 cases. Int J Reprod Contracept Obstet Gynecol 2017;6:2137-42. 